the vital question of the role of such antibodies in this malignant disease.

We have no clinical evidence that antibodies have any effect on the tumour when it is growing as a solid tumour. This is probably to be expected, as the concentration of antibody within a tumour may well be low and the conditions not favourable for any cytotoxic action to occur. Their presence, however, may prevent blood-borne metastases from forming. Possibly as long as cytotoxic antibodies are present in the serum malignant melanoma cells released into the blood are killed, but once these antibodies have disappeared malignant cells are no longer killed in the blood, and distant metastases form. Such a theory is highly speculative, but it fits with the clinical fact that this tumour may metastasize to the local lymph nodes, where it remains for variable periods of time before spreading via the blood stream. It also could explain why the disease disseminates by local lymphatic routes at a time when antibodies are present, but by the blood only when antibodies are absent. A similar situation has been encountered (Alexander and Hall, 1970) in rats with primary chemically-induced fibrosarcomata, which do not give rise to blood-borne metastases until antibody has been removed.
Clearly, more work is required to clarify the role of tumour-specific antibodies in human malignant melanoma; the reason remains to be establish 2 d why circulating antibodies disappear, and the possibility that the nodes draining the tumour become incapable of responding must be considered. Our work shows that this failure to respond is not systemic as it can be reversed by autografting.

This investigation has been supported by grants made to the Chester Beatty Research Institute by the British Empire Cancer Campaign and the Medical Research Council and a special grant by the Wellcome Foundation. The co-operation of many colleagues and centres rendered the work possible-in particular $\mathrm{Mr}$. W. P. Greening, Mr. J. D. Griffiths, Mr. J. A. McKinna, of the Royal Marsden Hospital, and Mr. G. Westbury, Professor Harold Ellis, Mr. E. S. Lee, and Mr. John Blake, of the Westminster Hospital. We also thank Miss L. E. Wheeler, Mrs. G. Bhatia, Mrs. L. Baker, Mrs. F. Torlot, and Mrs. S. F. B. Bell for technical assistance.

REFERENCES

Alexander, P., and Hall, J. G. (1970). Advances in Cancer Research. In press.

Lewis, M. G. (1967) Lancet, 2, 921.

Lewis, M. G., et al., (1969). British Medical fournal, 3, 547.

\title{
Clinical Significance of Dysuria in Women
}

\author{
W. E. WATERS, ${ }^{*}$ M.B., B.S., D.I.H. ; P. C. ELWOOD, ${ }^{*}$ M.D., D.P.H., D.C.H. \\ A. W. ASSCHER, $\dagger$ M.D., B.SC., M.R.C.P. ; MARGARET ABERNETHY
}

British Medical fournal, 1970, 2, 754-757

\begin{abstract}
Cummary: During a community survey $22 \%$ of women were found to have had dysuria in the previous year and half had had dysuria at some time in their lives. Various measurements were made in a random sample of 282 of these women. The means and the variances of the systolic and diastolic blood pressures in women with a past history of dysuria tended to be higher than in women who gave no such history. There were no significant differences in the means of plasma urea, plasma creatinine, and renal concentrating power between women with and without a previous history of dysuria, but a significant impairment of renal concentrating power was found in an additional group of 30 women who dated the onset of their dysuria to childhood.

These findings suggest that urinary tract infection in adult women does not usually lead to progressive impairment of kidney function, whereas infection in childhood is more often associated with kidney damage.
\end{abstract}

\section{Introduction}

Dysuria is a common symptom among women. A community survey showed that $22 \%$ of women aged 20 to 64 years had experienced dysuria in the year immediately preceding the survey and that $48 \%$ had had dysuria at some time in their lives (Waters, 1969). General practice studies suggest that more than half of all women presenting with dysuria are

* Member of Scientific Staff, M.R.C. Epidemiology Unit (South Wales),

Cardiff.
+ Senior Lecturer in Medicine, Welsh National School of Medicine,
Cardiff.

‡ Junior Technical Officer, M.R.C. Epidemiology Unit (South Wales), Cardiff. found to have bacteriological evidence of infection (Gallagher et al., 1965; Mond et al., 1965; Steensberg et al., 1969), and since nearly $30 \%$ initially without infection developed bacteriuria within three months (Gallagher et al., 1965), a comparison of kidney function among women with and without a history of dysuria may throw light on the long-term natural history of urinary tract infections. In particular it could indicate whether or not bacteriuria leads to impairment of kidney function. In this paper, therefore, the results of tests of kidney function and blood pressure measurements in women with and without a history of dysuria are compared. As dysuria in the distant past is often forgotten (Waters, 1969) it was considered desirable to pay particular attention to subjects with a history of dysuria in the year preceding the survey, when memory is likely to be more accurate. In fact there is evidence that a high proportion of these women are particularly liable to urinary tract symptoms. Since there is evidence (Smellie and Normand, 1968) that urinary tract infection in childhood is particularly apt to produce kidney damage, blood pressure and renal function studies have also been performed in a group of women who dated the onset of their dysuria to childhood.

\section{Methods}

The subjects who participated in this study were drawn randomly from 2,933 women aged 20 to 64 years who answered questions about symptoms referable to the urinary tract (Waters, 1969) and who represented over $86 \%$ of the population living in a defined area of a South Wales valley. The random sample consisted of 282 women, of whom 137 $(48 \%)$ gave a history of dysuria at some time in their lives 
and $56(20 \%)$ had had dysuria in the preceding year. Of the latter group $77 \%$ had also had dysuria before this period. Venous blood samples were taken from all 282 women and placed in heparinized tubes. The plasma was separated and deep-frozen. Plasma urea and plasma creatinine were measured with an AutoAnalyzer (Technicon methods $\mathrm{N}-1 \mathrm{c}$ and $\mathrm{N}-11 \mathrm{~b}$ ). Commercial standards were run with every set of determinations and a dozen duplicate samples were done blindly as a check of the reproducibility of the method.

These women were later visited in their homes and "cleancatch" specimens of urine were obtained and transported in refrigerated bags to a laboratory where they were examined for significant bacteriuria by a surface viable counting technique. The methods of urine collection and bacteriological examination were similar to those described by Sussman et al. (1969). Women with more than $10^{5}$ organisms per $\mathrm{ml}$. of urine in two consecutive specimens were classified as having significant bacteriuria. Blood pressure was estimated with a standard mercury manometer after the women had been sitting quietly for at least five minutes in their homes. The diastolic pressure was recorded as the level at which the sounds became muffled. All blood pressure readings were recorded to the nearest $5 \mathrm{~mm}$. Hg. Renal concentrating power was estimated by asking each woman to limit her fluid intake to not more than half a cupful after 6 p.m. and then collecting the first specimen of urine passed the following morning. The osmolality of this specimen was measured by the freezingpoint depression method with a Fiske osmometer (Advanced Instruments Inc.). The measurement of blood pressure and the instruction of the women for the test of renal concentrating power were done by two observers; each saw all the women living in separate defined areas. All other measurements were made by a single observer who was not familiar with the medical histories of the subjects in the study.

From the information obtained by questionary from the basic population of 2,933 women seen in the screening survey, $53(1.8 \%)$ said they had had their first attack of dysuria before the age of 15 years. Blood pressure measurements and the above tests of kidney function were carried out on a random sample of 30 of these women at the same time as the others were investigated.

Several of the variables measured in this survey showed significant regressions with age. In examining these data age was standardized by analyses of covariance.

\section{Results}

\section{Plasma Urea and Plasma Creatinine}

The mean urea and creatinine concentrations for women with and without dysuria in the previous year are shown in Table I. There was no significant difference (at $P<0.05$, the level of statistical significance used in this paper) between the means in any age group, nor was there a significant difference overall after standardizing for age. In both groups urea and creatinine concentrations increased significantly with age, and these associations are given by the regression equations:

$$
\begin{aligned}
& \text { Plasma urea }(\mathrm{mg} . / 100 \mathrm{ml} .)=16 \cdot 8+0.233 \times \text { age (in years) } \\
& \text { Plasma creatinine }(\mathrm{mg} . / 100 \mathrm{ml} .)=0.74+0.003 \times \text { age (in } \\
& \text { years) }
\end{aligned}
$$

There was no evidence of a significant difference in urea and creatinine concentrations between women with dysuria at any time in their lives and the rest of the population. Nor was there any evidence that women with high urea or high creatinine levels are significantly more likely to have had dysuria (Table II). Among the women with dysuria further small subgroups were examined to see if they differed from the rest of the population. These subgroups included 15 women ( $5 \%$ of the random sample) who had consulted their doctor for dysuria in the previous year, $21(7 \%)$ who had had dysuria for more than a total of two weeks in the previous year, and $41(14 \%)$ who said that they had had a rise in temperature with dysuria at some time in their lives. In none of these subgroups, after standardizing for age, was there any evidence of higher urea or creatinine concentrations.

TABLE II.-Proportion of Women with a History of Dysuria among those with High Values of Plasma Urea, Plasma Creatinine, and Systolic

\begin{tabular}{|c|c|c|c|c|}
\hline & & $\begin{array}{c}\text { No Dysuria } \\
\text { at Any Time }\end{array}$ & $\begin{array}{l}\text { Dysuria } \\
\text { at Some Time }\end{array}$ & $\begin{array}{c}\text { Difference } \\
\text { Between Groups }\end{array}$ \\
\hline Random sample & $\ldots$ & 145 & $137(48 \%)$ & - \\
\hline $\begin{array}{l}\text { Urea }>40 \mathrm{mg} . / 100 \mathrm{ml} . . . \\
\text { Creatinine }>1.1 \mathrm{mg} . / 100 \mathrm{ml} . \\
\text { Systolic blood pressure } \\
>160 \mathrm{~mm} . \mathrm{Hg} \\
\text { Diastolic blood pressure } \\
>95 \mathrm{~mm} . \mathrm{Hg} . \\
\text { Osmolality }<600 \mathrm{mOsm} . / \mathrm{kg} .\end{array}$ & $\begin{array}{l}\cdots \\
\cdots \\
\cdots \\
\cdots \\
\cdots\end{array}$ & $\begin{array}{r}10 \\
18 \\
11 \\
8 \\
33\end{array}$ & $\begin{array}{l}12(55 \%) \\
10(36 \%) \\
18(62 \%) \\
20(71 \%) \\
23(41 \%)\end{array}$ & $\begin{array}{c}0.5<\mathrm{P}<0.7 \\
0.1<\mathrm{P}<0.2 \\
0.1<\mathrm{P}<0.2 \\
0.01<\mathrm{P}<0.02 * \\
0.2<\mathrm{P}<0.3\end{array}$ \\
\hline
\end{tabular}
and Diastolic Blood Pressures, and among those with Low Urinary Osmolality (After Fluid Restriction-see Text)

*Significant

\section{Blood Pressure}

The mean diastolic blood pressures of women with and without dysuria in the previous year are shown in Table III. In both groups and with both observers there was a statistically significant increase in the mean diastolic pressure with age. For both observers the mean diastolic pressure and the regression coefficients of pressure on age were higher in women who had dysuria. Statistical evaluation of these results presents some difficulty, as for each observer the variance was significantly greater in the women with dysuria. Also, it is not appropriate to combine the observers' data as there was a significant difference between observers for the variance of the group without dysuria. The finding of a significant difference in mean diastolic pressures between those with and those without dysuria by Observer 2 (Table III) should therefore be interpreted with caution.

The mean systolic pressures showed a similar pattern to the diastolic pressures (Table III). In women with and without

Table I.-Mean Plasma Urea and Plasma Creatinine ( $\mathrm{mg} . / 100 \mathrm{ml}$.) and Standard Deviations in Women who had had Dysuria in the Previous Year and in Women who had not had Dysuria in the Previous Year (Number of Women in Each Group in Parentheses)

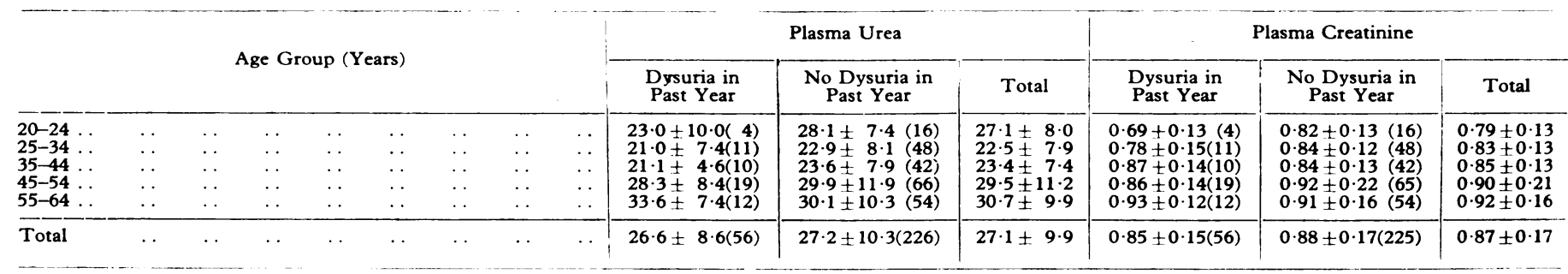


TABLE III.-Mean and Standard Deviations of Blood Pressures in Women who had had Dysuria in the Previous Year and in Women who had not had Dysuria in the Previous Year

\begin{tabular}{|c|c|c|c|c|c|c|c|c|c|c|c|c|c|c|}
\hline & & & & & & & \multicolumn{4}{|c|}{ Diastolic Pressure (mm. Hg) } & \multicolumn{4}{|c|}{ Systolic Pressure (mm. Hg) } \\
\hline & \multirow{2}{*}{\multicolumn{6}{|c|}{ Age Group (Years) }} & \multicolumn{2}{|c|}{ Observer 1} & \multicolumn{2}{|c|}{ Observer 2} & \multicolumn{2}{|c|}{ Observer 1} & \multicolumn{2}{|c|}{ Observer 2} \\
\hline & & & & & & & $\begin{array}{l}\text { Dysuria in } \\
\text { Past Year }\end{array}$ & $\begin{array}{l}\text { No Dysuria } \\
\text { in Past Year }\end{array}$ & $\begin{array}{l}\text { Dysuria in } \\
\text { Past Year }\end{array}$ & $\begin{array}{l}\text { No Dysuria } \\
\text { in Past Year }\end{array}$ & $\begin{array}{l}\text { Dysuria in } \\
\text { Past Year }\end{array}$ & $\begin{array}{l}\text { No Dysuria } \\
\text { in Past Year }\end{array}$ & $\begin{array}{l}\text { Dysuria in } \\
\text { Past Year }\end{array}$ & $\begin{array}{l}\text { No Dysuria } \\
\text { in Past Year }\end{array}$ \\
\hline $\begin{array}{l}20-24 \\
25-34 \\
35-44 \\
45-54 \\
55-64\end{array}$ & $\begin{array}{l}\cdots \\
\cdots \\
\cdots \\
\cdots\end{array}$ & $\begin{array}{l}\ldots \\
\cdots \\
\cdots \\
\cdots\end{array}$ & $\begin{array}{l}\cdots \\
\cdots \\
\cdots \\
\cdots\end{array}$ & $\begin{array}{l}. . \\
\cdots \\
\cdots \\
\cdots\end{array}$ & $\begin{array}{l}\cdots \\
\cdots \\
\cdots \\
\cdots\end{array}$ & $\begin{array}{l}\cdots \\
\cdots \\
\cdots \\
\cdots\end{array}$ & $\begin{array}{l}75 \cdot 0 \pm 6 \cdot 1 \\
78 \cdot 6 \pm 8 \cdot 5 \\
81 \cdot 7 \pm 18 \cdot 0 \\
93 \cdot 9 \pm 11 \cdot 1\end{array}$ & $\begin{array}{l}75 \cdot 0 \pm 5 \cdot 0 \\
79 \cdot 1 \pm 9 \cdot 6 \\
81 \cdot 3 \pm 7 \cdot 2 \\
83 \cdot 7 \pm 10 \cdot 4 \\
86 \cdot 0+10 \cdot 7\end{array}$ & $\begin{array}{l}78 \cdot 3 \pm 10 \cdot 4 \\
77 \cdot 5 \pm 6 \cdot 1 \\
85 \cdot 0 \pm 10 \cdot 0 \\
89 \cdot 3 \pm 14 \cdot 0 \\
93 \cdot 3 \pm 11 \cdot 5\end{array}$ & $\begin{array}{l}70 \cdot 7 \pm 6 \cdot 1 \\
76 \cdot 2 \pm 5 \cdot 5 \\
78 \cdot 8 \pm 6 \cdot 3 \\
82 \cdot 0 \pm 6 \cdot 0 \\
83 \cdot 4 \pm 8 \cdot 3\end{array}$ & $\begin{array}{ll} & \\
124 \cdot 0 & 14 \cdot 7 \\
125 \cdot 7 & 20 \cdot 3 \\
137 \cdot 1 & 30 \cdot 3 \\
153 \cdot 3 & 23 \cdot 2\end{array}$ & $\begin{array}{l}120 \cdot 0 \pm 9 \cdot 6 \\
127 \cdot 8+14 \cdot 2 \\
130 \cdot 5+14 \cdot 0 \\
136 \cdot 0+19 \cdot 7 \\
146 \cdot 3+17 \cdot 9\end{array}$ & $\begin{array}{l}133 \cdot 3+5 \cdot 8 \\
134 \cdot 2+4 \cdot 9 \\
140 \cdot 0+0 \cdot 0 \\
146 \cdot 4+15 \cdot 2 \\
155 \cdot 0+13 \cdot 2\end{array}$ & $\begin{array}{l}125 \cdot 0 \pm 4 \cdot 1 \\
130 \cdot 9 \pm 9.9 \\
135 \cdot 3 \pm 9 \cdot 6 \\
142 \cdot 6+7.5 \\
145 \cdot 9 \pm 11.0\end{array}$ \\
\hline Total & .. & $\ldots$ & & . & $\ldots$ & $\ldots$ & $83 \cdot 3+14 \cdot 5$ & $82 \cdot 6 \div 10 \cdot 1$ & $84 \cdot 6 \pm 11 \cdot 6$ & $79 \cdot 4 \pm 7 \cdot 4$ & $137 \cdot 1+26 \cdot 2$ & $135 \cdot 5+18 \cdot 5$ & $141 \cdot 5+12 \cdot 0$ & $137 \cdot 7+11 \cdot 2$ \\
\hline
\end{tabular}

dysuria, and with both observers, there was an increase with age. Again the variance was greater in those with a history of dysuria, and this difference is statistically significant with Observer 1. The data for the two observers cannot be combined because the variances between observers were significantly different.

Women with high blood pressure levels were more likely to have had dysuria, and in women with diastolic pressures of 95 $\mathrm{mm}$. $\mathrm{Hg}$ or above this difference was statistically significant (Table II).

\section{Renal Concentrating Power}

The mean osmolality (mOsm. $/ \mathrm{kg}$.) of urine specimens, after a period of limitation of fluid intake, decreased significantly with age. Unfortunately the use of two observers to give instructions to the women introduced significant variation. The data for each observer were therefore analysed separately. With neither observer was there a significant difference between the mean or variance of osmolality in women with and without a history of dysuria. The regression coefficient of osmolality on the age is -6.10 for Observer 1 and -8.25 for Observer 2.

\section{Dysuria Dating to Childhood}

Out of the total sample of 2,933 women originally interviewed, $53(1.8 \%)$ dated their first attack of dysuria to childhood (under 15 years of age). These women were significantly younger than the rest of the population. Table IV shows that they had more symptoms than women whose dysuria had its onset in adult life. A random sample of 30 of

TABLE IV.-Symptoms in Women who had had Dysuria in Childhood (53) and those in the Random Sample who had had Dysuria but not in Childhood (136)

\begin{tabular}{|c|c|c|c|}
\hline & $\begin{array}{l}\text { Dysuria } \\
\text { in } \\
\text { Childhood }\end{array}$ & $\begin{array}{c}\text { Dysuria but } \\
\text { not in } \\
\text { Childhood }\end{array}$ & $\begin{array}{l}\text { Difference } \\
\text { Between } \\
\text { Groups }\end{array}$ \\
\hline Dysuria in previous year & $29\left(55 n_{n}\right)$ & $56\left(41^{\circ}{ }_{0}\right)$ & $0.05-P<0.1$ \\
\hline $\begin{array}{l}\text { Dysuria for }>2 \text { weeks in } \\
\text { previous year } \\
\text { Consult doctor for dysuria: }\end{array}$ & $13\left(25^{\prime \prime}\right)$ & $21\left(15^{\prime \prime}, 1\right)$ & $0.1 \approx \mathrm{P}$. \\
\hline $\begin{array}{ll}\text { In previous year } & \ldots\end{array}$ & $\begin{array}{l}12\left(23^{n} n\right) \\
37\left(70^{n}\right)\end{array}$ & $\begin{array}{l}\left.15\left(11^{\circ}{ }^{\circ},\right)^{\prime}\right) \\
74\left(54{ }^{\prime \prime}\right)\end{array}$ & $\begin{array}{l}0.02 \cdot \mathrm{P}=0.05 * \\
0.05 \cdot \mathrm{P}=0.1\end{array}$ \\
\hline $\begin{array}{c}\text { Frequency of micturition with } \\
\text { dysuria }\end{array}$ & 42 & $90<66$ & $0.05<P<0.1$ \\
\hline $\begin{array}{l}\text { Pyrexia with dysuria } \\
\text { Dysuria - sometimes severe } \\
\text { Haematuria }\end{array}$ & $\begin{array}{l}24(450) \\
27(51 \\
16(30\end{array}$ & 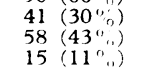 & $\begin{array}{r}0.02-\mathrm{P}<0.05^{*} \\
0.2 \cdot \mathrm{P}-0.3 \\
0.001-\mathrm{P}=0.01^{*}\end{array}$ \\
\hline & & & \\
\hline
\end{tabular}

-Significant.

these women was examined and their mean plasma urea, corrected for age, showed no significant difference from that of women who had never had dysuria. Similarly neither agecorrected mean plasma creatinine nor blood pressure showed any significant difference between these two groups. The renal concentrating power, however, did show a significant difference. After standardizing for age, women who had had dysuria in childhood showed a poorer concentrating ability.
The association between osmolality and age is given by the regression equations:

Dysuria in childhood: osmolality $(\mathrm{mOsm} . / \mathrm{kg})=.848-3.71 \times$ age (in years)

No dysuria at any time: osmolality (mOsm. $/ \mathrm{kg}$.) $=1047-6.46$ $x$ age (in years)

\section{Bacteriuria}

Clean midstream specimens of urine were obtained from 251 women $(89 \%)$ and $11(4.4 \%)$ had more than $10^{5}$ organisms per ml. of urine (significant bacteriuria) on two occasions. In all 11 cases the organism was Escherichia coli. Though the number of women with bacteriuria was small, significantly more of these had a past history of dysuria and other urinary tract symptoms. Two out of 26 women who had dysuria in childhood had significant bacteriuria.

\section{Discussion}

In this study kidney function tests in women with a history of dysuria were compared with tests in women who had. not had dysuria to unravel retrospectively the natural history of urinary tract infections. One of the difficulties of this epidemiological approach is that there is no entirely suitable simple test for measuring kidney function. The tests used in this survey are those normally performed as an initial screening of kidney function in hospital patients. The levels of urea and creatinine in the plasma of an individual patient, unless considerably raised, are an insensitive indication of glomerular function. Renal concentrating power is a sensitive index of tubular damage, but the degree of co-operation required is difficult to achieve in community studies.

Nevertheless, we consider that these tests are of value in epidemiological studies. While they may not be sensitive enough to be of much value in an individual subject, comparisons between mean levels in groups of subjects can be informative and are valid provided bias is absent. That this is so is suggested by the increase in the mean plasma urea and plasma creatinine levels, and the decline of the mean renal concentrating power, with increasing age. These findings are consistent with the known decline in kidney function with increasing age (Davies and Shock, 1950), and their presence in our data suggests that other trends and differences between means in the present data are meaningful.

We found no evidence that a history of dysuria in women is associated with any change in the plasma urea or plasma creatinine concentration, nor in the renal concentrating power. There is evidence, however, that women with a history of dysuria have a higher mean and a significantly greater variance for the diastolic and systolic blood pressures. Detailed examination of the data showed that this is not due to the inclusion of the women with bacteriuria, who are known to have significantly different blood pressures (Miall et al., 1962). These differences may be related to the facts that 
dysuria is commoner in women who have had children (Waters, 1969) whereas age-adjusted mean systolic and diastolic blood pressures decrease with the number of children (Miall and Oldham, 1958).

Fifty-three $(1.8 \%)$ of the women seen during the initial screening survey dated their first attack of dysuria to childhood. A comparison of symptoms in these women with those who had dysuria only in adult life suggests that their symptoms are more severe and more frequent and that they are more likely to consult a doctor (Table IV). After standardizing for age there is no evidence that their plasma urea, plasma creatinine, or blood pressure is different when compared with women who have never had dysuria. There is, however, evidence of a significant impairment of renal concentrating power. Loss of renal concentrating power is one of the earliest signs of chronic pyelonephritis, and the present finding suggests that dysuria in childhood is associated with kidney damage. The fact that women who report dysuria in childhood are significantly younger than the rest of the population could be the result of a higher mortality, but more probably this trend is simply an effect of memory.

Thus dysuria in women is unlikely to lead to impairment of kidney function but may be associated with higher than average blood pressure levels. In view of the large number of women with dysuria the present findings are on the whole reassuring, but they do not exclude the possibility that a few women with dysuria may develop kidney damage. There is no evidence of such a group in the numbers examined. Women with histories of dysuria in childhood, however, do show evidence of a decreased renal concentrating power, which suggests that in childhood this symptom is associated with kidney damage which persists into adult life.

We thank Professor A. L. Cochrane, Director of the M.R.C. Epidemiology Unit (South Wales), other members of the unit, and Dr. John Henry Jones, Miss Margaret Hopkins, and Mrs. Susan Chick, of the Cardiff Royal Infirmary, for their help in this survey.

\section{REFERENCES}

Davies, D. F., and Shock, N. W. (1950). Fournal of Clinical Investigation, 29, 496.

Gallagher, D. J. A., Montgomerie, J. Z., and North, J. D. K. (1965). British Medical fournal, 1, 622.

Miall, W. E., Kass, E. H., Ling, J., and Stuart, K. L. (1962). British Medical fournal, 2, 497

Miall, W. E., and Oldham, P. D. (1958). Clinical Science, 17, 409.

Mond, N. C., Percival, A., Williams, J. D., and Brumfitt, W. (1965). Lancet, 1, 514

Smellie, J. M., and Normand, I. C. 'S. (1968). In Urinary Tract Infec- O tion, Ed. F. O'Grady and W. Brumfitt, p. 123. London, Oxford $\vec{N}$ University Press.

Steensberg, J., Bartels, E. D., Bay-Nielsen, H., Fanøe, E., and Hede, T. Oे (1969). British Medical fournal, 4, 390.

Sussman, M., et al. (1969). British Medical fournal, 1, 799.

Waters, W. E. (1969). British fournal of Preventive and Social Medicine, N 23, 263.

\title{
Comparison of Pentazocine and Pethidine in Labour
}

\author{
J. MOWAT, ${ }^{*}$ F.R.C.S. (GLASG., ED.), M.R.C.O.G. ; M. M. GARREY, $\dagger$ D.P.H., F.R.C.o.G.
}

$\mathrm{S}^{\mathrm{u}}$ mmary: A double-blind between-patient study was carried out comparing pentazocine with pethidine in 94 women in labour. Similar analgesic and sedative effects were obtained with the two drugs, and Apgar scores were similar for babies of both drug groups. Fewer emetic sequelae were reported after pentazocine injections, though there was no statistically significant difference between the two drug groups in incidence of other sideeffects.

\section{Introduction}

Childbirth may be more exhausting than painful, but for most women the first stage of labour is accompanied by pain severe enough to warrant alleviation by some form of analgesia. Epidural anaesthesia has attractions, but, as well as needing medical and nursing staff, demands personal care by a specially skilled anaesthetist (Brandstater, 1966). The technique is not without risk and is unsuitable for domiciliary practice or a general-practitioner obstetric unit. Parenteral analgesics such as pethidine may be used, but these drugs all cross the placental barrier to varying degrees and may give rise to neonatal depression (Crawford, 1966). Thus new parenteral analgesics with advantages over the standard drugs should still be evaluated for use.

Pentazocine (Fortral) is of interest not only because the World Health Organization (1969) recommended that it should be free from narcotics control but also because Beckett and Taylor (1967) showed that pentazocine crosses the

* Senior Registrar, Royal Maternity Hospital, Glasgow C.4. tConsultant Obstetrician, Royal Maternity Hospital, Glasgow C.4. placenta to a lesser degree than pethidine. In addition, recent studies have shown pentazocine to have analgesic properties as good as or better than pethidine (Duncan, Ginsberg, and Morris, 1969; Moore, Carson, and Ball, 1970). Filler and Filler 후 (1966) regarded pentazocine as an effective analgesic which does not retard uterine contractility or the process of labour, 8 and Gonzales Munoz (1966) suggested that babies born to mothers who have been given pentazocine before childbirth 윽 have higher Apgar scores than babies born to mothers who $\mathrm{N}$ have been given pethidine.

In the present study pentazocine, in doses up to $60 \mathrm{mg}$, is compared with an equivalent dose of pethidine, up to 150 mg.; both drugs were given by intramuscular injection to patients requiring analgesia during the first stages of labour.

\section{Methods}

Ninety-four women aged 18 or over and more than 35 weeks pregnant were included in this double-blind betweenpatient comparison of intramuscular injections of pentazocine $\stackrel{\mathbb{D}}{\mathbb{D}}$

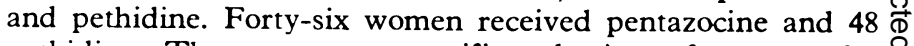
pethidine. There was no specific selection of women for inclusion in the trial, though patients were excluded if they were diabetic, had a history of hepatic or renal impairment, or $\delta$ were taking monoamine oxidase inhibitors. In addition the study was limited to patients who were para-three or less.

When labour was established and the mothers complained of pain-considered to be severe enough to require an analgesic, pentazocine or pethidine was given according to a predetermined random order. Results of the analgesic and sedative responses at one hour after each injection were analysed. Each patient received up to three injections of the test drugs, the 